\title{
THE IMPACT OF INTERNAL FACTORS ON SMALL BUSINESS SUCCESS: A CASE OF SMALL ENTERPRISES UNDER THE FELDA SCHEME
}

\author{
Khadijah Mohamad Radzi ${ }^{1}$, Mohammad Nazri Mohd Nor ${ }^{2}$, and \\ Suhana Mohezar Ali ${ }^{3 *}$ \\ ${ }^{1}$ Strategic Unit, Federal Land Development Authority, 50088 Kuala Lumpur, Malaysia \\ ${ }^{2}$ Department of Business Strategy \& Policy, Faculty of Business \& Accountancy, \\ University of Malaya, 50603 Kuala Lumpur, Malaysia \\ ${ }^{3}$ Department of Operations \& Information System, Faculty of Business \& Accountancy, \\ University of Malaya, 50603 Kuala Lumpur, Malaysia \\ *Corresponding author: suhanamohezar@um.edu.my
}

Published online: 30 June 2017

To cite this article: Mohamad Radzi, K., Mohd Nor, M.N., and Mohezar Ali, S. (2017). The impact of internal factors on small business success: A case of small enterprises under the FELDA scheme. Asian Academy of Management Journal, 22(1), 27-55. https://doi.org/10.21315/aamj2017.22.1.2

To link to this article: https://doi.org/10.21315/aamj2017.22.1.2

\begin{abstract}
This study attempts to identify the antecedents of business success in the Malaysian perspective, with particular reference to small businesses under the Federal Land Development Authority (FELDA) scheme. Cross sectional data were collected from 199 small businesses operating under the (FELDA) scheme via questionnaire. The data collected were analysed using partial least square method. The empirical results indicated that only entrepreneurial competency and technology usage are related to successes of small businesses. However, this study found insufficient empirical evidence to support the relationship between marketing capability, financial resources, knowledge sharing, and business success. As this study was confined to the small businesses under the FELDA scheme, this provides valuable findings by uncovering the differences among the critical success factors due to the different reasons for formation of the small businesses. The insights gained from this study could facilitate industry practitioners to develop comprehensive business strategies and effective institutional policies to maintain the global competitiveness of small businesses under the FELDA scheme.
\end{abstract}

Keywords: small business, business success, strategy, developing economy, FELDA

(C) Asian Academy of Management and Penerbit Universiti Sains Malaysia, 2017. This work is licensed under the terms of the Creative Commons Attribution (CC BY) (http://creativecommons. org/licenses/by/4.0/). 


\section{INTRODUCTION}

Research indicates that small businesses tend to have a higher failure rate as compared to large organisations, although they are commonly perceived as an engine of a country's economy (Bloch \& Bhattacharya, 2016; Lo, Wang, Wah, \& Ramayah, 2016). For example, in Malaysia, it was found that higher number of small and medium-sized enterprises (SMEs) indicated a worse performance in the first quarter of 2016 as compared to 2015 (SME Corp, 2016). Many failure stories of SMEs reveal that their characteristics which include reactive, fire-fighting mentality, resource limitations, informal strategies, flexible structures, and lack of strategic planning processes may have contributed to their failures (Gnizy, Baker, \& Grinstein, 2014).

The SMEs' success factors have captured the interest of many scholars and practitioners (Onkelinx, Manolova, \& Edelman, 2015; Khalique, Bontis, Shaari, \& Md. Isa, 2015; Javalgi \& Todd, 2011). Studies conducted by Onkelinx et al. (2015) reveal that business performance of a small firm is driven by entrepreneurial orientation, which is affected by the national culture and environment. Khalique et al. (2015) illustrate that human capital does not play a significant role in determining organisational performance in the Pakistani context. While human capital is generally understood as important antecedent factor in other related studies (Chen, Lin, \& Chang, 2006) Khalique et al. (2015) explain that being a developing economy, investment in training and development among Pakistani small businesses is woefully underrepresented, leading to inconsistent result. These existing studies demonstrate that firms in different context may react differently due to distinct economic and environment setting.

Within the Malaysian context, little work has been done to explore the business performance issue of small businesses that operate under the Malaysian Federal Land Development Authority (FELDA). This uneven focus has invited further investigation into this area of research. Despite the existing literature explaining the reasons for small business success; theories, concepts and practices developed in different contexts are not necessarily applicable to FELDA case. Moreover, scholars argue that the determinants of business success should be based on the context of research study is made, as they may be different from one context to the other (Lussier \& Pfeifer, 2001). In this line of argument, Yunus, Aris, Abdul Majid, and Md. Saad (2014) suggest that the FELDA settlers may have different entrepreneurial personality, and this may also affect the business performance. 
Initially, FELDA was a land development agency to materialise the national plan to eradicate poverty in the rural area of Malaysia back in 1956. After 50 years of operations, the agency has transformed itself from being an agricultural leader to a global corporate player (Mohamad et al., 2014). Efforts have been made to inculcate and develop the culture of entrepreneurship among the FELDA settlers specialising in small enterprise development for them. As the globalisation become the in-thing, these firms have a very important role of penetrating the local produce to the international markets, and working hard to compete with the established multinational competitors in the local markets. No doubt, globalisation has created opportunities for the small businesses under the FELDA scheme. However, the integration of the firms into international market may bring with the firms challenges (Idris, Salleh, \& Endut, 2014). Recognising this issue or phenomenon, there is a special need for a more deliberate study to rectify how these small businesses could succeed in the context they are in. This study therefore aims to examine the antecedents of business success among the small enterprises or businesses under the FELDA scheme. In determining the so-called business success factors, this study only focuses on the internal aspects. While businesses have also to be concerned with external macro environments which include political, social, economic, technology, and regulation, those factors are hardly controllable by management as they are in reality independent from the companies (Morrison \& Teixeira, 2004). Internal factors on the other hand, reveal how management preference and company characteristics influence any decisions that have to be made regarding resolving company issues or expansion plan of company's products and/or services (Makhija, 2003). Moreover, internal factors could also be regarded as a unique factor that includes firms' resources and capabilities that can be controlled (Galbreath \& Galvin, 2008). This unique factor explains the main reason for variations in the firms' performance despite of the same industry background with other firm(s) (Hirsch \& Schiefer, 2016). Thus, an internal factor is within a firm's control, which if properly utilised can help the firm to gain superior competitive advantage.

\section{CONCEPT DEVELOPMENT}

\section{Overview of Small Businesses under FELDA Scheme}

There is no universal definition of small businesses, with many authors offering various criteria including size, number of employees, and financial turnover per annum in the definition (Devins, 2009; Muhammad, Char, Yasoa, \& Hassan, 2010; Mahmood \& Hanafi, 2013). In spite of these various criteria, definitions are commonly based on employment in the Malaysian context. For example, in this 
study, small businesses are defined based on the Small and Medium Enterprise Corporation of Malaysia (SME Corp). The justification of using this definition is to ensure conformity of standards practiced among Malaysian researchers or policy makers. Furthermore, this classification of small businesses by SME Corp offers better cross-referencing purposes. For example, the SME Corp Malaysia defines a small business as one that employs between 5 to 75 full-time employees and has sales turnover between RM300,000 to RM15 million for the manufacturing sector; and 5 to 30 full-time employees and has sales turnover between RM300,000 to RM3 million for the services sector (SME Corp, 2016).

The Malaysian government has acknowledged the importance to develop the small businesses' capabilities as this strategy can help to broaden the sources of economic growth (SME Corp, 2016). The small business firm's capabilities can be developed, for example, by forming a strategic collaboration between SME Corp and FELDA. Beginning in 2005, FELDA has initiated an Entrepreneurial Development Program (Mohamad et al., 2014) in an effort to develop and encourage entrepreneurship and businesses among its settlers. By conducting such programme, the organisation hopes to increase the family income, which in turn can promote and enhance the quality of life among the settlers. As this looks good, various tremendous efforts have been implemented by FELDA under the programme. For instance, in an effort to increase the efficiency and delivery capacity, as well as to widen the distribution of small enterprises products, the agency has worked closely with respective firms in terms of developing their business premises by way of halal compliance and implementing good manufacturing practices. Apart from that, they also help the businesses to strengthen their promotional activities so that there is an increase in brand awareness in the local food industry (Ismail \& Yusop, 2014).

With attempts as above, in 2014, there were approximately 21,796 businesses established by FELDA settlers, with sales recorded at RM1.9 billion. This figure is expected to grow at a rate of 5 per cent every year (FELDA, 2015). Moreover, the income generated by the small businesses under this scheme has indirectly increased the economic status of the settlers' families while reducing their dependencies on agricultural commodities. This also has resolved social issues and reduced migration of young generation to big cities owing to their unemployment factor. Given FELDA's contribution towards the country's and settlers' economy, it is therefore imperative to investigate any issues arising from the small enterprises that operate under the FELDA scheme that can affect the growth of those enterprises. The manifold contributions indicate the successfulness of the programme, which could be emulated in other entrepreneurship programmes. 


\section{Business Success}

Business success is about the achievement of goals and objectives of a company, which is not explicitly defined (Ngwangwama, Ungerer, \& Morrison, (2013); Foley \& Green, 1989). It can also be characterised as a firm's ability to create acceptable outcomes and actions (Van Praag, 2003; Marom \& Lussier, 2014). There is no universal acceptable definition of business success and a majority of management studies measure business success from the perspective of firms' performance (Van Auken \& Werbel, 2006; Reijonen \& Komppula, 2007; Wang \& Wang, 2012). In fact, firm performance is also complex and has multidimensional facets. Additionally, according to Islam, Khan, Obaidullah, and Alam (2011), there are at least two pertinent dimensions of business success: (1) financial vs. nonfinancial, and (2) short- vs. long-term success. Based on this contend, there are various ways to measure business success that includes survival, profits, return on investment, sales growth, number of personnel employed, happiness, corporate reputation, and others (Schmidpeter \& Weidinger, 2014).

Similarly, for the context of small businesses, many early attempts at understanding firms' performance were made with reference to financial ratios and accounting measures (Shailer, 1989). However, few scholars (Riquelme \& Watson, 2002) argued that there is lack of reliability with financial ratios and accounting data, as majority of small businesses have no formal reporting requirements on these financial data. Due to these reasons, it becomes impossible to obtain sufficient reliable information to measure the small businesses' success. Further to this thought, Wieder, Booth, Matolcsy, and Ossimitz (2006) added to the argument that financial accounting measures are not able to tap the essence of a firm's performance in other aspects as well, such as customer service, quality of products produced, innovation, and operational efficiency. Relying on financial data also limits the ability to explain future performance as they are historically oriented, hence can be misleading (Koufteros, Verghese, \& Lucianetti, 2014). In the background of recent political and social developments, there are many other non-financial factors that should be included to make the measurement of firm performance more effective (Abdallah \& Alnamri, 2015). Given these arguments, this study therefore only incorporated non-financial measures, which can be captured through managerial perceptions. The rationale for non-financial measures is that with limited information available on financial data of small businesses, it is impossible to quantify the respondents' performance using financial accounting measures. 


\section{Attributes of Business Success through the Resource-Based View Theory}

In determining the factors that affect business success factors of small businesses under the FELDA scheme, we adopted the resource-based view (RBV) theory. The theory contends that the key to improve a firm's performance is based on the firm's internal characteristics (Barney, 2001). The differences in performance are explained primarily by the existence of an organisation's resources which are valuable, rare, and not easily imitated and substitutable by rivalry (Barney, 2001). Prior to addressing the small business resource criteria, it is beneficial to define what resource is. Resources are those tangible and intangible assets owned by a firm (Galbreath, 2005). Tangible assets include financial resources, physical resources (plant, equipment, machine, etc.), human resources, and technological resources; while intangible assets refer to knowledge, skills, reputation, and capabilities. Usually, firms seek to acquire and exercise permanent or semi-permanent control over resources that can offer competitive advantage over the firms' competitors. As firms may apply different levels of control over various types of resources, they would be unique from each other in terms of offering different products or services. Organisational assets such as human resources, management policies, and capabilities are used by firms to develop and implement strategies or new innovations in those firms. Human capitals with high levels of skills and achieved good alignment between the skills represented in the firm and those required by its strategic needs will have positive impact on the firm (Crook, Todd, Combs, Woehr, $\&$ Ketchen, 2011). Hence, the main reason for firms' growth and success is actually coming from inside the firms. In other words, firms with superior resources and capabilities will build up a basis for gaining and sustaining competitive advantage.

The RBV theory is of particular relevance in the small business context, as it contends that long-term survival is dependent upon the firm's unique offerings. The development of this uniqueness over time is by nurturing the organisation's core competencies. It is widely accepted that small enterprises are often faced with a lack of resources, and this forces them to operate under severe financial and expertise constraints (Phillipson, Bennett, Lowe, \& Raley 2004,; Zucchella $\&$ Siano, 2014). Moreover, inadequate resources issue can often influence these firms to focus on short-term rather than long-term goals, inhibit them from further development and exploitation of opportunities existing in the environment. Hence, the RBV perspective comes in handy as it offers an opportunity to analyse the small business success that are associated with internal resources and capabilities. 
Table 1 provides a summary of past empirical works and attributes that are found to be associated with a business' success. As shown in Table 1, the list of attributes found to be associated with business success is extensive. Yet, of the most cited attributes (referred to by at least 20 authors), it could be argued that entrepreneurial competency which includes the skills, educational background, know-how, and personal motivations/goals appear to be the main contributing factor for small business success. The next factor relates to financial resources. Small businesses are often cited as facing restricted access to funds and instead rely on personal sources of finance in place. Consequently, limited financial access may restrict larger investments that require a longer payback period, creating a growth and development barrier in these organisational settings (Jasra, Hunjra, Rehman, Azam, \& Khan, 2011; Kim, Knotts, \& Jones, 2008). Hence, access to finance has been featured prominently in a number of studies as a constraint on small businesses development.

In addition to a firm's accessibility to resources, quite a number of studies have related business success with marketing capability (Kim et al. 2008; Coy, Shipley, Omer, \& Khan, 2007; Bowen, Morara, \& Mureithi, 2009). Marketing capability has been considered the domain of large firms previously; yet this dimension is argued to be as important with increased globalisation (O'Cass \& Sok, 2013). In other words, most of the SME's operating internationally tend to have less marketing resources, do less market research and lack presence in large readily accessible markets, as well as have less well recognised brands (Merrilees, Rundle-Thiele, \& Lye, 2011). Some studies have also recognised the importance of SMEs in ensuring knowledge is used and shared optimally within the firm by way of developing analytical and critical skills of individuals in order to sustain and reap competitive advantage (Egbu, Hari, \& Renukappa, 2005; Ngah \& Jusoff, 2009). Their focus has been primarily stemmed from the RBV theory. The theory suggests that the underlying unique competitive advantage of small businesses is centred on the capacity to learn (Barney, 2001). Nevertheless, these firms' resource poverty can lead to information deficit, as technology also plays an important role in this respect. In support, different studies (Thurik, 2007; Fink \& Disterer, 2006; Raymond \& Bergeron, 2008) have also revealed that lack of technology and equipment are impediments of small business success. Based on these prior empirical studies, this study anticipates that the FELDA's small business success is influenced by the five factors discussed earlier which includes financial resources, entrepreneurial competency, marketing capabilities, technology usage, and knowledge sharing. 
Khadijah Mohamad Radzi et al.

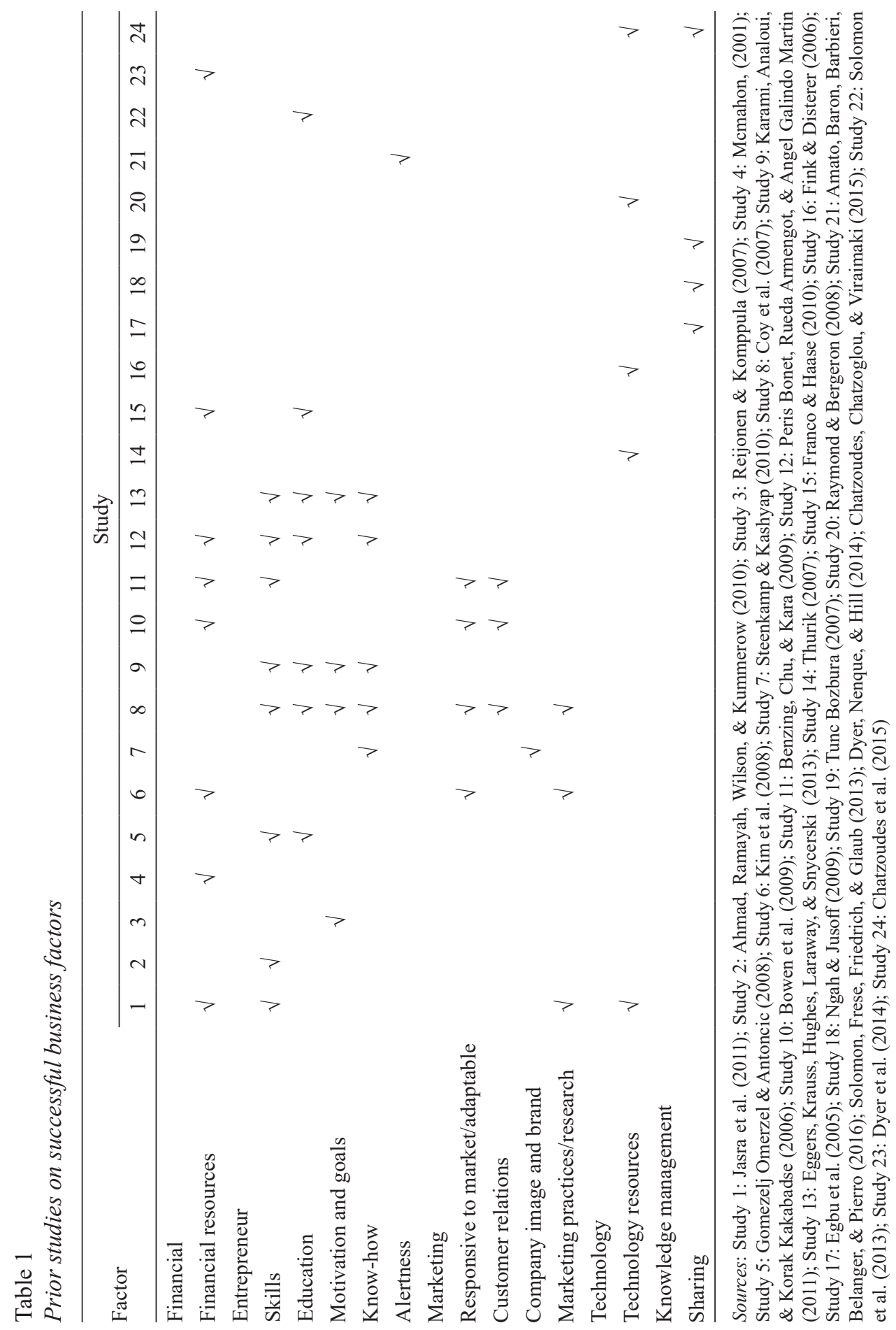




\section{CONCEPTUAL FRAMEWORK AND HYPOTHESES DEVELOPMENT}

Based upon the relevant literature, a conceptual framework was developed (Figure 1). The hypothesized model identifies a set of five variables covering entrepreneurial competency, marketing capability, financial resources, technology usage, and knowledge sharing as influencing the business success of FELDA SMEs.

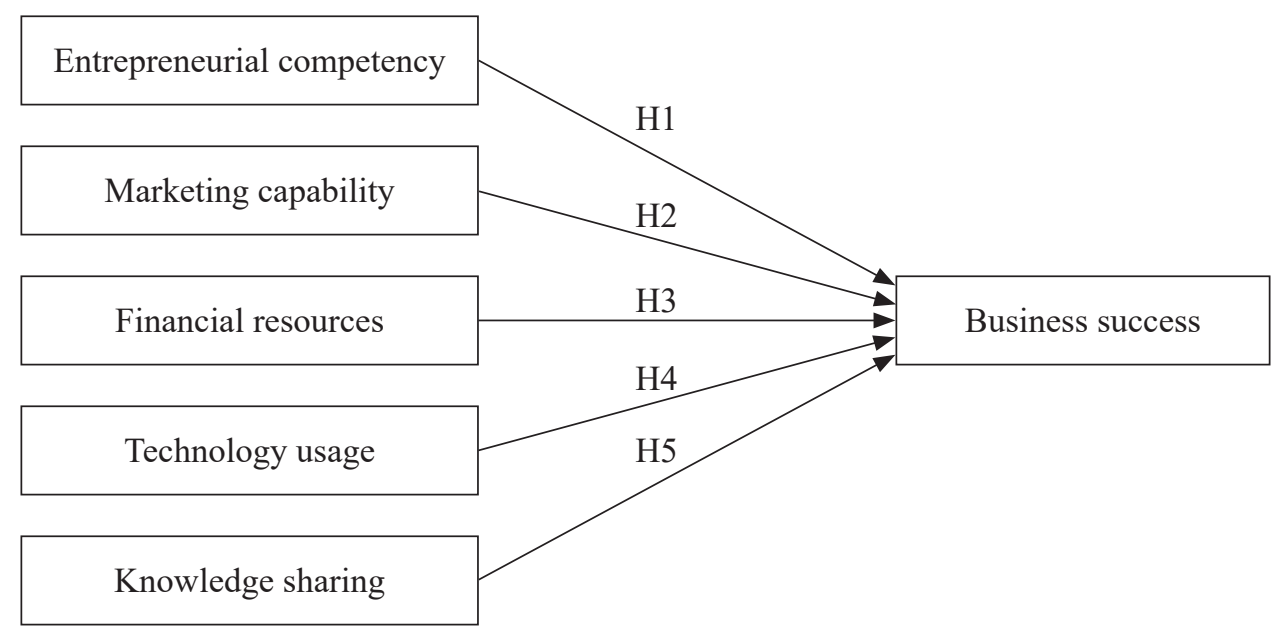

Figure 1. Research framework

Entrepreneurial competency refers to the small business owners' knowledge, skills and abilities (achieved via education, training, and experience), effectiveness of interpersonal relationships, network effects, and communication skills (Coleman, 2007; Collins-Dodd, Gordon, \& Smart, 2004). Prior empirical works have established a relationship between entrepreneurial competency and business success (Coy et al., 2007; Karami et al., 2006; Eggers et al., 2013). It therefore becomes relevant to acknowledge that business owners, particularly in the small business context, act as a gatekeeper. These business owners enable the internal resources of a firm to be optimised in order to achieve business success (Ahmad et al., 2010). According to Amato et al. (2016) and Peris Bonet et al. (2011), the owner's attributes can drive motivation, positively impacting communication, and supporting an adaptive organisation. An owner that possesses entrepreneurial characteristics has the ability to recognise opportunities and transform these opportunities into a business activity, ultimately influencing the venture's success (Jasra et al., 2011). Specifically, Amato et al. (2016) argue that an entrepreneur who are more alert to their physical surrounding could acts independently in bringing forth a business concept or vision and able to carry a task through completion, 
leading to business success. Additionally, entrepreneurs in successful firms are also found to have the willingness to support creativity, experimentation, possess forward-looking perspective, and demonstrate efforts to outperform industry competitors (Coy et al., 2007; Karami et al., 2006; Bowen et al., 2009; Peris Bonet et al., 2011; Eggers et al., 2013). Based upon these arguments, this study postulates that:

H1: Entrepreneurial competency is positively related to business success of FELDA's small businesses.

The resource based theory has suggested marketing capability as part of imitable organisational resources that may offer a potential basis for sustainable competitive advantage (Kozlenkova, Samaha, \& Palmatier, 2014). Marketing capability refers to a company's ability to utilise its tangible and intangible resources to understand complex consumers' needs and ultimately achieve superior brand recognition (Nath, Nachappan, \& Ramanathan, 2010). Differentiation strategy through new product and service development is believed to be able to facilitate firms in sustaining their competitive advantage (Vinayak \& Kodali, 2014). However, these firms may not be able to reap the economic returns yet as potential customers may not fully aware of the uniqueness embedded in the products or services purchased (Agrawal \& Bhuiyan, 2014). The unique features or characteristics may not be easily spotted by the customers at a first glance. This is because businesses need to have a good marketing capability to raise awareness of the individuals interested in purchasing the products (Chin, Lo, \& Ramayah, 2013). Specifically within the context of small enterprises, marketing capability is often handicapped by poor resources including lack of cash flow and marketing expertise to handle statistical and strategic customer-related matters (Doole, Grimes, \& Demack, 2006; O'Dwyer, Gilmore, \& Carson, 2009). Despite this, small businesses strive hard to focus on their marketing capability as they believe that it is the key for competitiveness. Prior studies highlight (Kim et al., 2008; Steenkamp \& Kashyap, 2010; Benzing et al., 2009) that small enterprises are able to offer great attention, friendly, and outstanding services as well as customised products since they usually target the small markets. All these are done to achieve business performance. Moreover, the rapid globalisation has forced them to acquire marketing strength in order to compete with the big firms (O'Cass \& Sok, 2013). Additionally, appropriate resources need to be undertaken to ensure the small firms could develop and execute the right marketing mix strategies against the competitors (Benzing et al., 2009). Following these arguments, this study therefore postulates that:

H2: Marketing capability is positively related to business success of FELDA's small businesses. 
There are various empirical studies verifying the importance of financial resources for successful business of small firms (Jasra et al., 2011; Bowen et al., 2009; Dyer et al., 2014). While financial resources are vital for an organisation to ensure smooth operation, small enterprises often have comparatively limited resources and additionally face greater difficulty in accessing funding sources (Peris Bonet et al., 2011). They are also found to have less adequate budgetary control system and because they are still small businesses they lack the economies of scales (Thurik, 2007). Sufficient financial resources are also required for the firms to make continuous investment in terms of employee training and education, and to initiate any innovation process in an effort to sustain their competitive advantage (Dyer et al., 2014). Following this trait, this study postulates that:

H3: Financial resources are positively related to business success of FELDA's small businesses.

The strategic importance of technological usage is well acknowledged in the literature as a factor that could enhance business success (Jasra et al., 2011; Raymond \& Bergeron, 2008; Chatzoudes et al., 2015). Firms that utilise the latest technology tend to capture customers more than their competitors (Valacich \& Schneider, 2014). Specifically, small firms that have timely access to technical, industry knowledge, and insights into the latest technological breakthrough will be more successful. By adopting information and communication technologies, this can ease collaboration between small enterprises and their supply chain partners (Greene, Brush, \& Brown, 2015). Moreover, technologies such as the e-marketplace for instance, may allow firms to expand globally and enter into new markets that before were inaccessible due to geographical barriers, with a minimum cost (White, Daniel, Ward, \& Wilson, 2007). This in turn would facilitate firms to gain and sustain competitive advantage. Few studies on small business performance have associated a strong link between technology resources and business success (Chatzoudes et al., 2015; Dibrel, Davis, \& Craig, 2008; Kim et al., 2008). Those studies reported that information technology as vital for the small business to sustain innovation, promote customer loyalty, and stimulate demand for other products offered by the small business. Following these arguments, this study postulates that:

H4: Technology usage is positively related to business success of FELDA's small businesses.

Knowledge sharing has gained increased attention among researchers and managers as it can assist firms in optimising business goals and helps firms to foster individual and organisational learning (Desouza \& Awazu, 2006; Erikkson 
\& Li, 2012). Purposeful sharing of useful knowledge for rapid individual and organisational learning can lead to innovation and development of better products, thus enhancing market performance (Egbu et al., 2005; Ngah \& Jusoff, 2009; Chatzoudes et al., 2015). Small businesses tend to provide an environment that is conducive to generate knowledge due to their size and closer social relationships of employees, resulting in good communication flows that foster knowledge sharing (Chase, 2004). Since small firms are often supported by their cooperation and relationship-building with mostly local customers, they have less bureaucratic organisational structure, hence knowledge sharing can become uncontrollable (Desouza \& Awazu, 2006). Knowledge should be the means for small businesses to overcome poor business environment and change the complex business environment to be manageable (Ngah \& Jusoff, 2009). They normally compete on their know-how and use the knowledge to their advantage since they do not have sufficient financial resources to spend on land, labour, and capital. Based on these arguments, this study postulates that:

H5: Knowledge sharing is positively related to business success of FELDA's small businesses.

\section{RESEARCH METHODOLOGY}

\section{Measure of Constructs}

The constructs used in this study are measures adopted from the literature and adapted to suit the context of the study. Entrepreneurial competency was measured using five items adapted from Islam et al. (2011). These items assessed the levels of small business owners' personality in terms of innovativeness, leadership skills, and reactiveness. Meanwhile, seven items measuring marketing capability were adapted from Chittithaworn, Islam, Keawchana, and Yusuf (2011). These items measured the extent of a company's ability in utilising its resources to understand complex consumer needs and offer superior product, as well as achieve brand recognition. Four items measuring the level of financial resources were adapted from Cook and Nixson (2000). Based on Hove and Tarisai (2013), four items measuring technology usage were adapted. They measured the extent of information technology usage in processing business transactions, and communicating with suppliers and customers. Next, knowledge sharing was measured using four items adapted from Li and Lin (2006) while six items measuring perceived business success were extracted from Chittithaworn et al. (2011). 


\section{Survey Administration and Sample}

This study employed the survey method, which is using the questionnaire to test the conceptual model and hypotheses developed. The questionnaire was pilot tested on a sample of 20 entrepreneurs coming from small business enterprises. The feedback (e.g., inconsistency of wording, unclear or ambiguous items) from the pilot test was used to refine the questions for a larger study. The sample of this study was extracted from a population of 13,323 small business enterprises under the FELDA scheme that registered with SME Corp in February 2015. The stratified random sampling technique based on geographical location was used to avoid cases in which some members of the population were significantly under or over represented by the sample. The sample was divided into Northern region, Southern region, East Coast region and East Malaysia region. Subsequently, we used the systematic sampling technique to select and contact every 26th consecutive enterprise on the list, in order to yield a total of 500 firms. The questionnaires, including a cover letter in self-addressed and stamped envelopes, were mailed to the owners. Of the 500 questionnaires mailed out, 199 were returned, resulting in a $39.8 \%$ response rate. Table 2 presents the sample characteristics. Majority of the responding firms were from the manufacturing industry, with less than 10 employees. Most of them have established their businesses for about three to five years.

Since the response rate was only $39.8 \%$, the validity and generalisability of the findings may be compromised by non-response bias. Being such, we conducted an assessment of the non-response bias by comparing the responses between the early and late respondents using an independent t-test (Armstrong \& Overton, 1977). Early respondents were those who had completed and returned the questionnaires within the initial one-month response window, while late respondents refer to those who returned the questionnaires after the specified response period. Approximately $70 \%$ of the responses were from the early respondents. The results of the independent t-test showed that there was no significant difference between early and late responses, as the $p$-values were above 0.05 , indicating that a nonresponse bias did not occur in the dataset (Table 3). Additionally, an independent t-test was also performed to assess for potentially confounding effects associated with dispersed geographical location. Our results found no statistically significant differences, as the $p$-value were above 0.05 (see Table 4). 
Khadijah Mohamad Radzi et al.

Table 2

Sample characteristics

\begin{tabular}{|c|c|c|c|}
\hline & & Frequency & Percentage \\
\hline \multirow[t]{2}{*}{ Industry } & Services & 66 & 33.2 \\
\hline & Manufacturing & 133 & 66.8 \\
\hline \multirow[t]{6}{*}{ Year in business } & $<3$ & 42 & 21.1 \\
\hline & $3-5$ & 46 & 23.1 \\
\hline & $6-10$ & 68 & 34.2 \\
\hline & $11-15$ & 23 & 11.6 \\
\hline & $16-20$ & 7 & 3.5 \\
\hline & $>20$ & 13 & 6.5 \\
\hline \multirow[t]{6}{*}{ Annual sales revenue } & $<$ RM 50,000 & 87 & 43.7 \\
\hline & RM50,000-RM100,000 & 52 & 26.1 \\
\hline & RM101,000-RM250,000 & 36 & 18.1 \\
\hline & RM251,000-RM500,000 & 12 & 6.0 \\
\hline & RM501,000-RM1,000,000 & 9 & 4.5 \\
\hline & $>\mathrm{RM} 1,000,000$ & 3 & 1.5 \\
\hline \multirow[t]{3}{*}{ Number of employees } & $5-10$ & 163 & 81.9 \\
\hline & $10-15$ & 21 & 10.6 \\
\hline & $15-19$ & 15 & 7.5 \\
\hline \multirow[t]{4}{*}{ Location } & Northern region & 51 & 25.6 \\
\hline & Southern region & 55 & 27.6 \\
\hline & East Coast region & 48 & 24.1 \\
\hline & East Malaysia & 45 & 22.6 \\
\hline
\end{tabular}

Table 3

Assessment of non-response bias

\begin{tabular}{lcccc}
\hline Factors & $\begin{array}{c}\text { Early respondents } \\
(\mathrm{n}=143)\end{array}$ & $\begin{array}{c}\text { Late respondents } \\
(\mathrm{n}=56)\end{array}$ & t-value & Significant \\
\hline Entrepreneurial competency & 4.23 & 4.25 & 1.22 & 0.24 \\
Marketing capability & 4.87 & 4.80 & 1.20 & 0.18 \\
Financial resources & 4.39 & 4.42 & 1.10 & 0.13 \\
Knowledge sharing & 3.20 & 3.30 & 1.20 & 0.21 \\
Technology usage & 4.33 & 4.32 & 0.56 & 0.45 \\
Business success & 4.30 & 4.28 & 1.08 & 0.11 \\
\hline
\end{tabular}


Table 4

Assessment of confounding effects associated with geographical locations

\begin{tabular}{lcccccc}
\hline Factors & $\begin{array}{c}\text { Northern } \\
\text { region } \\
(\mathrm{n}=57)\end{array}$ & $\begin{array}{c}\text { Southern } \\
\text { region } \\
(\mathrm{n}=55)\end{array}$ & $\begin{array}{c}\text { East Coast } \\
\text { region } \\
(\mathrm{n}=48)\end{array}$ & $\begin{array}{c}\text { East } \\
\text { Malaysia } \\
(\mathrm{n}=45)\end{array}$ & t-value & Significant \\
\hline Entrepreneurial competency & 4.21 & 3.98 & 4.05 & 4.02 & 1.01 & 0.56 \\
Marketing capability & 4.17 & 4.28 & 4.22 & 4.01 & 1.00 & 0.58 \\
Financial resources & 4.13 & 4.05 & 4.12 & 4.10 & 0.22 & 0.55 \\
Knowledge sharing & 3.11 & 3.11 & 3.06 & 3.00 & 0.11 & 0.61 \\
Technology usage & 4.03 & 4.12 & 4.22 & 4.11 & 1.01 & 0.52 \\
Business success & 4.28 & 4.23 & 4.02 & 4.11 & 1.05 & 0.22 \\
\hline
\end{tabular}

\section{ANALYSIS AND RESULTS}

\section{Validity and Reliability}

First, a convergent validity test was performed to assure that the multiple items that were used to measure the constructs are in agreement. As suggested by Hair, Hult, Ringle, and Sarstedt (2013), the factor loadings, composite reliability, and average variance extracted were used as indicators to assess the convergent validity. The loadings for all items exceeded the recommended value of 0.5 (Bagozzi, Yi, \& Singh, 1991). The composite reliability values, ranged from $0.77-0.87$, which exceeded the recommended value of 0.7 (Hair et al., 2013). The average variance extracted were in the range of $0.50-0.64$, which exceeded the recommended value of 0.5 (Hair et al., 2013). Table 5 depicts the results of convergent validity.

Second, a discriminant validity test was conducted to assure that the measures do not reflect other variables. It is indicated by low correlations between the measure of interest and the measures of other constructs (Cheung \& Lee, 2010). As suggested by Fornell and Larcker (1981), discriminant validity can be examined by comparing the squared correlations between the constructs and the variance extracted for a construct. As shown in Table 6, all the scales appeared to have a substantially higher average variance extracted value compared to their squared correlation with other constructs, providing evidence that there was discriminant validity. In total, the measurement model demonstrated adequate convergent and discriminant validity. 
Khadijah Mohamad Radzi et al.

Table 5

Convergent validity

\begin{tabular}{|c|c|c|c|c|c|}
\hline Constructs & & Items & $\begin{array}{l}\text { Factor } \\
\text { loadings }\end{array}$ & $\mathrm{CR}$ & AVE \\
\hline \multirow[t]{5}{*}{$\begin{array}{l}\text { Entrepreneurial } \\
\text { competency }\end{array}$} & EO1 & $\begin{array}{l}\text { I have an ambitious goal with clear } \\
\text { vision and mission to run my business }\end{array}$ & 0.77 & 0.87 & 0.60 \\
\hline & $\mathrm{EO} 2$ & $\begin{array}{l}\text { I have a characteristics of autonomy, } \\
\text { competitive aggressiveness and risk } \\
\text { taking }\end{array}$ & 0.76 & & \\
\hline & EO3 & $\begin{array}{l}\text { I am motivated and have high confident } \\
\text { to run my business well }\end{array}$ & 0.82 & & \\
\hline & EO4 & I am innovative and proactive & 0.80 & & \\
\hline & EO5 & $\begin{array}{l}\text { I have good leadership skills, reliable } \\
\text { managerial skills, and decision-making } \\
\text { skills }\end{array}$ & 0.71 & & \\
\hline \multirow[t]{6}{*}{$\begin{array}{l}\text { Marketing } \\
\text { capability }\end{array}$} & MP1 & $\begin{array}{l}\text { My company has a good service and } \\
\text { delivery system }\end{array}$ & 0.80 & 0.86 & 0.62 \\
\hline & MP2 & $\begin{array}{l}\text { My company has a good knowledge of } \\
\text { customers and their needs }\end{array}$ & 0.81 & & \\
\hline & MP3 & $\begin{array}{l}\text { My company has a good image and } \\
\text { reputation }\end{array}$ & 0.78 & & \\
\hline & MP4 & We have good quality product/service & 0.76 & & \\
\hline & MP5 & $\begin{array}{l}\text { We have effective sales skills, } \\
\text { marketing and promotion activities }\end{array}$ & 0.77 & & \\
\hline & MP6 & $\begin{array}{l}\text { My company has high ability to find } \\
\text { quick solutions for changing customer } \\
\text { needs }\end{array}$ & 0.82 & & \\
\hline \multirow[t]{4}{*}{$\begin{array}{l}\text { Financial } \\
\text { resources }\end{array}$} & OR1 & $\begin{array}{l}\text { My company has a good financial base } \\
\text { and adequate cash resources }\end{array}$ & 0.74 & 0.82 & 0.53 \\
\hline & OR2 & $\begin{array}{l}\text { We have a good accounting practice } \\
\text { and systems to manage our operations }\end{array}$ & 0.64 & & \\
\hline & OR3 & $\begin{array}{l}\text { We make use of public financial } \\
\text { support and grants }\end{array}$ & 0.76 & & \\
\hline & OR4 & $\begin{array}{l}\text { We keep track of financial reports on } \\
\text { the sales, purchase, income statement, } \\
\text { and balance sheet }\end{array}$ & 0.77 & & \\
\hline
\end{tabular}

(continue on next page) 
Table 5 (continued)

\begin{tabular}{|c|c|c|c|c|c|}
\hline Constructs & & Items & $\begin{array}{l}\text { Factor } \\
\text { loadings }\end{array}$ & $\mathrm{CR}$ & AVE \\
\hline \multirow[t]{4}{*}{$\begin{array}{l}\text { Knowledge } \\
\text { sharing }\end{array}$} & KM1 & $\begin{array}{l}\text { Employees in my company share } \\
\text { know-how from work experience with } \\
\text { each other }\end{array}$ & 0.77 & 0.88 & 0.51 \\
\hline & KM2 & $\begin{array}{l}\text { Employees in my company share } \\
\text { expertise obtained from education and } \\
\text { training methods }\end{array}$ & 0.69 & & \\
\hline & KM3 & $\begin{array}{l}\text { Employees in my company share } \\
\text { business knowledge obtained } \\
\text { informally (such as news stories and } \\
\text { gossip) }\end{array}$ & 0.77 & & \\
\hline & KM4 & $\begin{array}{l}\text { Employees in my company share } \\
\text { business knowledge from partners } \\
\text { (such as customers, suppliers, and } \\
\text { allies) }\end{array}$ & 0.60 & & \\
\hline \multirow[t]{4}{*}{$\begin{array}{l}\text { Technology } \\
\text { usage }\end{array}$} & TU1 & $\begin{array}{l}\text { My company uses webpages, email, } \\
\text { and e-commerce technologies for } \\
\text { business purposes }\end{array}$ & 0.78 & 0.77 & 0.64 \\
\hline & TU2 & $\begin{array}{l}\text { Our company's information could be } \\
\text { accessed by customers and suppliers } \\
\text { through internet }\end{array}$ & 0.78 & & \\
\hline & TU3 & $\begin{array}{l}\text { We use the internet to learn on the } \\
\text { industry trends }\end{array}$ & 0.82 & & \\
\hline & TU4 & $\begin{array}{l}\text { Our company uses online systems to do } \\
\text { banking transactions, applying permits, } \\
\text { paying taxes, and others }\end{array}$ & 0.81 & & \\
\hline \multirow[t]{6}{*}{ Business success } & BS1 & $\begin{array}{l}\text { I am happy with the way my business } \\
\text { is operated }\end{array}$ & 0.72 & 0.82 & 0.50 \\
\hline & $\mathrm{BS} 2$ & $\begin{array}{l}\text { I am satisfied with the growth of net } \\
\text { income of the business }\end{array}$ & 0.59 & & \\
\hline & BS3 & I consider my business as successful & 0.58 & & \\
\hline & BS4 & I consider my business as growing & 0.79 & & \\
\hline & BS5 & $\begin{array}{l}\text { My business will continue to expand in } \\
\text { the future }\end{array}$ & 0.72 & & \\
\hline & BS6 & $\begin{array}{l}\text { The company's market share is growing } \\
\text { from year to year }\end{array}$ & 0.79 & & \\
\hline
\end{tabular}


Khadijah Mohamad Radzi et al.

Table 6

Discriminant validity

\begin{tabular}{lcccccccc}
\hline & Mean & SD & EO & MP & FR & KM & TU & BU \\
\hline Entrepreneurialcompetency (EO) & 4.12 & 0.25 & $\mathbf{0 . 7 7}$ & & & & & \\
Marketing capability (MP) & 4.74 & 0.36 & 0.42 & $\mathbf{0 . 7 9}$ & & & & \\
Financial resources (OR) & 4.34 & 0.42 & 0.57 & 0.51 & $\mathbf{0 . 7 3}$ & & & \\
Knowledge sharing (KM) & 3.21 & 0.65 & 0.52 & 0.25 & 0.32 & $\mathbf{0 . 7 1}$ & & \\
Technology usage (TU) & 4.15 & 0.12 & 0.62 & 0.33 & 0.40 & 0.32 & $\mathbf{0 . 8 0}$ & \\
Business success (BS) & 4.32 & 0.66 & 0.65 & 0.62 & 0.41 & 0.32 & 0.55 & $\mathbf{0 . 7 1}$ \\
\hline
\end{tabular}

Note: The numbers in bold in the diagonal row are square roots of the AVE; SD = standard deviations

\section{Assessment of Structural Model}

Assuming that the hypothesized measurement model satisfied the validity and reliability assessment, we proceeded with hypothesis testing. The predictive accuracy of the model was evaluated in terms of the portion of variance explained. The results revealed that the model is capable of explaining $30.3 \%$ of the variance in business success. Nonparametric bootstrapping was applied (Hair et al., 2013) with 5,000 replications to test the structural model. The significance of direct effects specified by the research model was evaluated (Table 7 ). The results revealed that the effects of entrepreneurial competency $(\beta=0.27, p<0.001)$ and technology usage $(\beta=0.22, p<0.001)$ on business success are positive and significant. In contrast, the effect of marketing capability $(\beta=0.14, p=0.06)$, financial resources $(\beta=0.13, p=0.12)$ and knowledge sharing $(\beta=0.02, p=0.76)$ on business success are non-significant. From these results, $\mathrm{H} 1$ and $\mathrm{H} 5$ are supported while H2, H3, and $\mathrm{H}_{4}$ are rejected.

\section{DISCUSSION}

This study utilises the RBV theory to determine the antecedents of business success. This study has extended prior empirical works by focusing specifically on small businesses under the FELDA scheme. Based on the RBV theory, two variables were found to be congruent with the existing research.

The significant role of entrepreneurial competency highlights that the business owner plays a vital role in succeeding the business. This finding is supported by prior research works (Peris Bonet et al., 2011; Eggers et al., 2013) . Since small firms are constraint by size and operated by the owners, strong entrepreneurial characteristics are important in determining the success of organisations. For small 
Table 7

Structural model analysis

\begin{tabular}{|c|c|c|c|c|c|}
\hline Hypothesis & Relationships & $\begin{array}{l}\text { Path } \\
\text { coefficients }\end{array}$ & Decision & t-value & $\begin{array}{l}\text { Standard } \\
\text { error }\end{array}$ \\
\hline H1 & $\begin{array}{l}\text { Entrepreneurial competency } \rightarrow \\
\text { Business success }\end{array}$ & $0.27 * * *$ & Supported & 3.74 & 0.02 \\
\hline $\mathrm{H} 2$ & $\begin{array}{l}\text { Marketing capability } \rightarrow \text { Business } \\
\text { success }\end{array}$ & 0.14 & $\begin{array}{c}\text { Not } \\
\text { supported }\end{array}$ & 1.25 & 0.01 \\
\hline $\mathrm{H} 3$ & $\begin{array}{l}\text { Financial resources } \rightarrow \text { Business } \\
\text { success }\end{array}$ & 0.13 & $\begin{array}{c}\text { Not } \\
\text { supported }\end{array}$ & 1.22 & 0.01 \\
\hline $\mathrm{H} 4$ & $\begin{array}{l}\text { Knowledge sharing } \rightarrow \text { Business } \\
\text { success }\end{array}$ & 0.02 & $\begin{array}{c}\text { Not } \\
\text { supported }\end{array}$ & 1.08 & 0.00 \\
\hline H5 & $\begin{array}{l}\text { Technology usage } \rightarrow \text { Business } \\
\text { success }\end{array}$ & $0.22 * * *$ & Supported & 3.66 & 0.05 \\
\hline
\end{tabular}

$* * * p<0.001$

businesses, the owners are involved in all decision roles in the organisation. As a result, there is less dependency on formal decision models and more reliance on the owners' institution (Kelliher \& Reinl, 2009). Owing to this factor, the owner needs to be an expert in all fields of management. Besides that, the owner also needs to be capable of motivating and nurturing employees to get them to consistently cooperate to ensure competitive advantage is always achieved; thereby company is sustained. The owner's capability to become proactive and aggressive in initiatives to alter the competitive scene to the advantage of firms facilitate in improving the company's performance. This characteristic is necessary in helping many responding firms to face the rapidly changing environment and meet the varying emerging customers' requirements (Coy et al., 2007; Karami et al., 2006; Eggers et al., 2013).

In this study, we also found that the success of small businesses under the FELDA scheme is also shaped by technology usage. From our results, it appears that business owners who are able to integrate IT into their business processes and activities could enhance their business growth. Small businesses that are often faced with financial capital problems may face limitation in terms of their participation in economic activities. However, their participation in information technology could facilitate them in gaining cost-effective operations. For example, the use of e-marketplace may help these businesses to expand into new markets and select suppliers that offer services and products at lower, but competitive prices (Stockdale \& Standing, 2004). Perhaps, a lack of technology resources over time may render the firm incapable of meeting customers' changing requirements (Dibrell et al., 2008). 
Past studies have highlighted the importance of financial resources in determining the small business success (Jasra et al., 2011; Bowen et al., 2009; Dyer et al., 2014). Small firms are often faced with restrictions in innovation activities due to restricted financial resources, hence limiting their business success. Nevertheless, in this study, the effect of financial resources is found to be non-significant to the responding firms' business success. A probable reason for this finding is that being a developing country, the small firms in Malaysia are largely dependent on the public sector to foster and sustain their growth (Muhammad et al., 2010; Hashim, 2012). For this study, FELDA intervention in providing funding could provide impetus for the small businesses to achieve business success. For example, FELDA has allocated RM100 million in interest free loans for the small businesses to purchase equipment and machinery (Aziz, Hassan, \& Saud, 2012). Apart from that, FELDA has also cooperated with other agencies in providing training for human capital development in the area of business management, financial, marketing, and product development. With so much opportunities provided by FELDA, these small businesses may not perceive financial resources as limiting them to achieve business success.

While there are substantial researches that reported an association between business success and knowledge sharing (Egbu et al., 2005; Ngah \& Jusoff, 2009; Chatzoudes et al., 2015), this study appears to have found insufficient empirical evidence to support this contention. This phenomenon occurs, perhaps due the low level of participation on such practice among employees of small firms (Durst \& Runar Edvardsson, 2012). Moreover, due to the lack of financial resources and expertise, small firms' day-to-day business operations needed close attention, resulting in insufficient time available to resolve strategic issues. This situation may result in most knowledge being kept in the minds of the owner and some key employees instead of stored or shared with substitution arrangement or with the other employees (Durst \& Wilhelm, 2012). While the use of technology in conducting business transactions is common among the small scale businesses under the FELDA scheme they do not possess systems in place like data warehouse and decision support system that make full use of the technology infrastructure (Aziz et al., 2011) to facilitate knowledge sharing practice. Therefore, it is unlikely for the responding firms to exploit the benefits.

Similar to knowledge sharing, this study also found non-significant effect of marketing capability on business success. This is probably because the sampling firms do not have the right characteristics; as a result generating the contradicting results. Since the responding firms consisted of small businesses, they may not even have a strategic marketing plan (Farhangmehr, 2015). In the context of FELDA, most of the entrepreneurs are more likely to focus on their day-to-day operations 
(Jamak, Ali, \& Ghazali, 2014). They prefer to venture into small scale businesses or undertake contract work that is within their settlement's perimeter. As a result, most of the products produced are similar, with basic packaging strategy. This factor may cause the business owners to have lesser concern for the marketing and product strategy plan.

\section{IMPLICATION AND CONCLUSION}

This study offers theoretical and practical contributions by demonstrating the applicability of the RBV theory in determining the critical internal factors, that is, factors that may lead to FELDA small business success. Despite the various past studies on business success factors among small businesses, their results may not be easily generalised. This is due to the fact that small businesses often aim to achieve a variety of financial and non-financial goals, leading to reduced comparability of the findings across multiple firms. For example, in the context of FELDA, these firms are formed not only due to economic reasons, but also the formation is aimed at reducing social issues and migration of young generation to big cities. Hence, this research improves our understanding by uncovering the differences of critical success factors as a result of the different settings. Despite this limitation, this study has provided additional evidence to support the importance of entrepreneurial competency and technology usage as these factors are capable of enhancing business success of FELDA's small businesses.

In fact, the owners or managers of the businesses under the scheme have to recognise and thereafter consider the strategic role of technology as this can increase efficiency, performance, and competitiveness. Various technologies can be applied to enhance business activities such as inventory management, distribution, manufacturing, and even customer service. For example, the use of bar code systems in managing the retail operations could help the small businesses to identify products electronically, and facilitate inventory control and replenishment activities at the store level (De Marco, Cagliano, Nervo, \& Rafele, 2012). Moreover, the IT tools are utilised to transmit, communicate, and share information within the business entity and supply chain partners. Therefore, IT needs to be capitalised effectively to support quality information and knowledge management.

The important role of entrepreneurial competency in ensuring successful business suggests a need for the government and FELDA to continue providing appropriate training and advice. For example, various training workshops to educate the business owners on the efficient utilisation of farming systems, watering regimes, pruning and harvesting machinery, as well as good supply chain practice provides 
the opportunity to upskill the community. Apart from that, FELDA can also initiate the provision of training programmes that are aimed at developing entrepreneurial character building. This entrepreneurial competency acquired can assist firms in becoming proactive in terms of gaining first-mover advantages which can facilitate firms to acquire premium market segments and predict the market ahead of competitors. This is important to be exercised, particularly with the increasingly competitive global market. Lack of entrepreneurial competency among the business owners is not impactful; instead could result in the companies being excluded from the supply chain.

Despite the fact that this study is able to extend the relevant literature relating to critical success factors of small businesses, the present study contains some limitations. This is because our data was only confined to small firms under the FELDA scheme, this may limit the generalisability of the finding. Nevertheless, this study appears to provide first-hand information and approximation that enables one to better understand the internal success factors of FELDA's small businesses by applying the RBV theory. It has been our earnest hope that this study was able to provide empirical evidence with regards to small business critical success factors. The insights that have been gained from this study could facilitate industry practitioners to develop comprehensive business strategies and effective institutional policies to maintain the global competitiveness of small businesses, particularly those that are in the FELDA scheme.

\section{REFERENCES}

Abdallah, W.M., \& Alnamri, M. (2015). Non-financial performance measures and the BSC of multinational companies with multi-cultural environment: An empirical investigation. Cross Cultural Management, 22(4), 594-607. https://doi. org/10.1108/CCM-12-2013-0195

Agrawal, A., \& Bhuiyan, N. (2014). Achieving success in NPD projects. World Academy of Science, Engineering and Technology, International Journal of Social, Behavioral, Educational, Economic, Business and Industrial Engineering, 8(2), 476-481.

Ahmad, H.N., Ramayah, T., Wilson, C., \& Kummerow, L. (2010). Is entrepreneurial competency and business success relationship contingent upon business environment? A study of Malaysian SMEs. International Journal of Entrepreneurial Behavior \& Research, 16(3), 182-203. https://doi. org $/ 10.1108 / 13552551011042780$

Amato, C., A. Baron, R., Barbieri, B., Bélanger, J.J., \& Pierro, A. (2016). Regulatory modes and entrepreneurship: The mediational role of alertness in small business success. Journal of Small Business Management. https://doi.org/10.1111/jsbm.12255 
Armstrong, J.S., \& Overton, T.S.(1977). Estimating nonresponse bias in mail surveys.Journal of Marketing Research, 14(3), 396-402. https://doi.org/10.2307/3150783

Aziz, N.N.A., Hassan, W.H.A.W., \& Saud, N.A. (2012). The effects of urbanization towards social and cultural changes among Malaysian settlers in the Federal Land Development Schemes (FELDA), Johor Darul Takzim. Procedia-Social and Behavioral Sciences, 68, 910-920. https://doi.org/10.1016/j.sbspro.2012.12.276

Bagozzi, R.P., Yi, Y., \& Singh, S. (1991). On the use of structural equation models in experimental designs: Two extensions. International Journal of Research in Marketing, 8(2), 125-140. https://doi.org/10.1016/0167-8116(91)90020-8

Barney, J.B. (2001). Resource-based theories of competitive advantage: A ten-year retrospective on the resource-based view. Journal of Management, 27(6), 643650. https://doi.org/10.1177/014920630102700602

Benzing, C., Chu, H.M., \& Kara, O. (2009). Entrepreneurs in Turkey: A factor analysis of motivations, success factors, and problems. Journal of Small Business Management, 47(1), 58-91. https://doi.org/10.1111/j.1540-627X.2008.00262.x

Bloch, H., \& Bhattacharya, M. (2016). Promotion of innovation and job growth in smalland medium-sized enterprises in Australia: Evidence and policy issues. Australian Economic Review, 49(2), 192-199. https://doi.org/10.1111/1467-8462.12164

Bowen, M., Morara, M., \& Mureithi, S. (2009). Management of business challenges among small and micro enterprises in Nairobi-Kenya. KCA Journal of Business Management, 2(1), 16-31. https://doi.org/10.4314/kjbm.v2i1.44408

Chase, R. L. (2004). Knowledge networks. Journal of Knowledge Management, 8(3), 3-5.

Chatzoudes, D., Chatzoglou, P., \& Viraimaki, E. (2015). The central role of knowledge management in business operations: Developing a new conceptual framework. Business Process Management Journal, 21(5), 1117-1139. https://doi. org/10.1108/BPMJ-10-2014-0099

Chen, Y.S., Lin, M.J.J., \& Chang, C.H. (2006). The influence of intellectual capital on new product development performance: The manufacturing companies of Taiwan as an example. Total Quality Management and Business Excellence, 17(10), 13231339. https://doi.org/10.1080/14783360601058979

Cheung, C.M., \& Lee, M.K. (2010). A theoretical model of intentional social action in online social networks. Decision Support Systems, 49(1), 24-30. https://doi. org/10.1016/j.dss.2009.12.006

Chin, C.H., Lo, M.C., \& Ramayah, T. (2013). Market orientation and organizational performance. Sage Open, 3(4). https://doi.org/10.1177/2158244013512664

Chittithaworn, C., Islam, M.A., Keawchana, T., \& Yusuf, D.H.M. (2011). Factors affecting business success of small and medium enterprises (SMEs) in Thailand. Asian Social Science, 7(5), 182-190. https://doi.org/10.5539/ass.v7n5p180

Coleman, S. (2007). The role of human and financial capital in the profitability of growth of women-owned small firms. Journal of Small Business Management, 45(3), 303-319. https://doi.org/10.1111/j.1540-627X.2007.00214.x

Collins-Dodd, C., Gordon, I., \& Smart, C. (2004). Further evidence on the role of gender in financial performance. Journal of Small Business Management, 42(4), 395-416. https://doi.org/10.1111/j.1540-627X.2004.00119.x 
Collis, J., \& Hussey, R. (2013). Business research: A practical guide for undergraduate and postgraduate students. United Kingdom: Palgrave Macmillan.

Cook, P., \& Nixson, F. (2000). Finance and small and medium-sized enterprise development. Manchester: Institute for Development Policy and Management, University of Manchester.

Coy, S.P., Shipley, M.F., Omer, K., \& Khan, R.N.A. (2007). Factors contributory to success: A study of Pakistan's small business owners. Journal of Developmental Entrepreneurship, 12(2), 181-198. https://doi.org/10.1142/S1084946707000617

Crook, T.R., Todd, S.Y., Combs, J.G., Woehr, D.J., \& Ketchen Jr, D.J. (2011). Does human capital matter? A meta-analysis of the relationship between human capital and firm performance. Journal of Applied Psychology, 96(3), 443-456. https://doi. org/10.1037/a0022147

De Marco, A., Cagliano, A.C., Nervo, M.L., \& Rafele, C. (2012). Using system dynamics to assess the impact of RFID technology on retail operations. International Journal of Production Economics, 135(1), 333-344. https://doi.org/10.1016/j. ijpe.2011.08.009

Desouza, K.C. \& Awazu, Y. (2006). Knowledge management at SMEs: Five peculiarities. Journal of Knowledge Management, 10(1), 32-43. https://doi. org/10.1108/13673270610650085

Devins, D. (2009). Enterprise in deprived areas: What role for start-ups? International Journal of Entrepreneurship and Small Business, 8(4), 486-498. https://doi. org/10.1504/IJESB.2009.025694

Dibrell, C., Davis, P.S., \& Craig, J. (2008). Fueling innovation through information technology in SMEs. Journal of Small Business Management, 46(2), 203-218. https://doi.org/10.1111/j.1540-627X.2008.00240.x

Doole, I., Grimes, T., \& Demack, S. (2006). An exploration of the management practices and processes most closely associated with high levels of export capability in SMEs. Marketing Intelligence \& Planning, 24(6), 632-647. https://doi. org/10.1108/02634500610701690

Durst, S., \& Runar Edvardsson, I. (2012). Knowledge management in SMEs: A literature review. Journal of Knowledge Management, 16(6), 879-903. https://doi. org $/ 10.1108 / 13673271211276173$

Durst, S., \& Wilhelm, S. (2012). Knowledge management and succession planning in SMEs. Journal of Knowledge Management, 16(4), 637-649. https://doi. org/10.1108/13673271211246194

Dyer, W.G., Nenque, E., \& Hill, E.J. (2014). Toward a theory of family capital and entrepreneurship: Antecedents and outcomes. Journal of Small Business Management, 52(2), 266-285. https://doi.org/10.1111/jsbm.12097

Egbu, C.O., Hari, S., \& Renukappa, S.H. (2005). Knowledge management for sustainable competitiveness in small and medium surveying practices. Structural Survey, 23(1), 7-21. https://doi.org/10.1108/02630800510586871

Eggers, F., Kraus, S., Hughes, M., Laraway, S., \& Snycerski, S. (2013). Implications of customer and entrepreneurial orientations for SME growth. Management Decision, 51(3), 524-546. https://doi.org/10.1108/00251741311309643 
Erikkson. J., \& Li. M. (2012). Success factors of entrepreneurial small and medium sized enterprises in the Gnosjö municipality. Master dissertation, Malardalen University, Sweden.

Farhangmehr, M. (2015). Contribution of strategic marketing planning to the performance of small and medium sized firms: An empirical research. In M. Sirgy, K. Bahn, \& T. Erem (Eds.), Proceedings of the 1993 World Marketing Congress (pp. 4348). Developments in Marketing Science: Proceedings of the Academy of Marketing Science. Springer, Cham. https://doi.org/10.1007/978-3-319-17323814

FELDA (2015). Annual report. Retrieved 5 December 2016 from http://www.feldaglobal. com/ investors/annual-reports/.

Fink, D., \& Disterer, G. (2006). International case studies: To what extent is ICT infused into the operations of SMEs? Journal of Enterprise Information Management, 19(6), 608-624. https://doi.org/10.1108/17410390610708490

Foley, P., \& H. Green (Eds.). (1989). Small business success. London: Chapman.

Fornell, C., \& Larcker, D.F. (1981). Structural equation models with unobservable variables and measurement error: Algebra and statistics. Journal of Marketing Research, 18(3), 382-388. https://doi.org/10.2307/3150980

Franco, M., \& Haase, H. (2010). Failure factors in small and medium-sized enterprises: Qualitative study from an attributional perspective. International Entrepreneurship and Management Journal, 6(4), 503-521. https://doi.org/10.1007/s11365-0090124-5

Galbreath, J. (2005). Which resources matter the most to firm success? An exploratory study of resource-based theory. Technovation, 25(9), 979-987. https://doi. org/10.1016/j.technovation.2004.02.008

Galbreath, J., \& Galvin, P. (2008). Firm factors, industry structure and performance variation: New empirical evidence to a classic debate. Journal of Business Research, 61(2), 109-117. https://doi.org/10.1016/j.jbusres.2007.06.009

Gnizy, I., Baker, W.E., \& Grinstein, A. (2014). Proactive learning culture: A dynamic capability and key success factor for SMEs entering foreign markets. International Marketing Review, 31(5), 477-505. https://doi.org/10.1108/IMR-10-2013-0246

Gomezelj Omerzel, D., \& Antoncic, B. (2008). Critical entrepreneur knowledge dimensions for the SME performance. Industrial Management \& Data Systems, 108(9), 1182-1199. https://doi.org/10.1108/02635570810914883

Greene, P.G., Brush, C.G., \& Brown, T.E. (2015). Resources in small firms: An exploratory study. Journal of Small Business Strategy, 8(2), 25-40.

Hair Jr, J.F., Hult, G.T.M., Ringle, C., \& Sarstedt, M. (2013). A primer on partial least squares structural equation modeling (PLS-SEM). Thousand Oaks: Sage Publications.

Hashim, F. (2012). Challenges for the internationalization of SMEs and the role of government: The case of Malaysia. Journal of International Business and Economy, 13(1), 97-122.

Hirsch, S., \& Schiefer, J. (2016). What causes firm profitability variation in the EU food industry? A redux of classical approaches of variance decomposition. Agribusiness, 32(1), 79-92. https://doi.org/10.1002/agr.21430 
Hove, P., \& Tarisai, C. (2013). Internal factors affecting the successful growth and survival of small and micro agri-business firms in Alice communal area. Journal of Economics, 4(1), 57-67.

Idris, N.A.H., Salleh, N.H.M., \& Endut, W. (2014). Downstream activities at the FELDA land development scheme: Analysis on motivational factors of women's participation in business activities. Asian Social Science, 10(15), 143. https://doi. org/10.5539/ass.v10n15p143

Islam, M.A., Khan, M.A., Obaidullah, A.Z.M., \& Alam, M.S. (2011). Effect of entrepreneur and firm characteristics on the business success of small and medium enterprises (SMEs) in Bangladesh. International Journal of Business and Management, 6(3), 289-299.

Ismail, M.M., \& Yusop, Z. (2014). Competitiveness of the Malaysian food processing industry. Journal of Food Products Marketing, 20(Supp.1), 164-178. https://doi. org/10.1080/10454446.2014.921872

Jamak, A.B.S.A., Ali, R.M.M., \& Ghazali, Z. (2014). A breakout strategy model of Malay (Malaysian indigenous) micro-entrepreneurs. Procedia-Social and Behavioral Sciences, 109, 572-583. https://doi.org/10.1016/j.sbspro.2013.12.509

Jasra, J.M., Hunjra, A.I., Rehman, A.U., Azam, R.I., \& Khan, M.A. (2011). Determinants of business success of small and medium enterprises. International Journal of Business and Social Science, 2(20), 274-280.

Javalgi, R.R.G., \& Todd, P.R. (2011). Entrepreneurial orientation, management commitment, and human capital: The internationalization of SMEs in India. Journal of Business Research, 64(9), 1004-1010. https://doi.org/10.1016/j.jbusres.2010.11.024

Karami, A., Analoui, F., \& Korak Kakabadse, N. (2006). The CEOs' characteristics and their strategy development in the UK SME sector: An empirical study. Journal of Management Development, 25(4), 316-324. https://doi. org/10.1108/02621710610655800

Kelliher, F., \& Reinl, L. (2009). A resource-based view of micro-firm management practice. Journal of Small Business and Enterprise Development, 16(3), 521-532. https:// doi.org/10.1108/14626000910977206

Khalique, M., Bontis, N., Shaari, J.A.N., \& Md. Isa, A.H. (2015). Intellectual capital in small and medium enterprises in Pakistan. Journal of Intellectual Capital, 16(1), 224-238. https://doi.org/10.1108/JIC-01-2014-0014

Kim, K.S., Knotts, T.L., \& Jones, S.C. (2008). Characterizing viability of small manufacturing enterprises (SME) in the market. Expert Systems with Applications, 34(1), 128-134. https://doi.org/10.1016/j.eswa.2006.08.009

Koufteros, X., Verghese, A.J., \& Lucianetti, L. (2014). The effect of performance measurement systems on firm performance: A cross-sectional and a longitudinal study. Journal of Operations Management, 32(6), 313-336. https://oi.org/ 10.1016/j.jom.2014.06.003

Kozlenkova, I.V., Samaha, S.A., \& Palmatier, R.W. (2014). Resource-based theory in marketing. Journal of the Academy of Marketing Science, 42(1), 1-21. https://doi.org/10.1007/s11747-013-0336-7 
Li, S., \& Lin, B. (2006). Accessing information sharing and information quality in supply chain management. Decision Support Systems, 42(3), 1641-1656. https://doi. org/10.1016/j.dss.2006.02.011

Lo, M.C., Wang, Y.C., Wah, C.R.J., \& Ramayah, T. (2016). The critical success factors for organizational performance of SMEs in Malaysia: A partial least squares approach. Revista Brasileira de Gestão de Negócios / Review of Business Management, 18(61), 370. https://doi.org/10.7819/rbgn.v18i61.3058

Lussier, R., \& Pfeifer, S. (2001). A cross-national prediction model for business success. Journal of Small Business Management, 39(3), 228-237.

Mahmood, R., \& Hanafi, N. (2013). Entrepreneurial orientation and business performance of women-owned small and medium enterprises in Malaysia: Competitive advantage as a mediator. International Journal of Business and Social Science, 4(1), 82-90

Makhija, M. (2003). Comparing the resource-based and market-based views of the firm: Empirical evidence from Czech privatization. Strategic Management Journal, 24(1): 433-451. https://doi.org/10.1002/smj.304

Marom, S., \& Lussier, R.N. (2014). A business success versus failure prediction model for small businesses in Israel. Business and Economic Research, 4(2), 63-81. https:// doi.org/10.5296/ber.v4i2.5997

Mcmahon, R.G. (2001). Growth and performance of manufacturing SMEs: The influence of financial management characteristics. International Small Business Journal, 19(3), 10-28. https://doi.org/10.1177/0266242601193001

Merrilees, B., Rundle-Thiele, S., \& Lye, A. (2011). Marketing capabilities: Antecedents and implications for B2B SME performance. Industrial Marketing Management, 40(3), 368-375. https://doi.org/10.1016/j.indmarman.2010.08.005

Mohamad, Z., Noor, R.M., Tapah, S., Talib, J., Mamat, M., Hassan, W.Z.W., \& Yunos, N. (2014). Rural land management in Malaysia: Referring to the role of Federal Land Development Authority (FELDA). Middle-East Journal of Scientific Research, 22(1), 18-25.

Moorthy, M.K., Tan, A., Choo, C., Wei, C.S., Ping, J.T.Y., \& Leong, T.K. (2012). A study on factors affecting the performance of SMEs in Malaysia. International Journal of Academic Research in Business and Social Sciences, 2(4), 224.

Morrison, A., \& Teixeira, R. (2004). Small business performance: A tourism sector focus. Journal of Small Business and Enterprise Development, 11(2), 166-173. https://doi.org/10.1108/14626000410537100

Muhammad, M.Z., Char, A.K., bin Yasoa, M.R., \& Hassan, Z. (2010). Small and medium enterprises (SMEs) competing in the global business environment: A case of Malaysia. International Business Research, 3(1), 66.

Nath, P., Nachappan S., \& Ramanathan, R. (2010). The impact of marketing capability, operations capability and diversification strategy on performance: A resourcebased view. Industrial Marketing Management, 39(2), 317-329. https://doi.org/ 10.1016/j.indmarman.2008.09.001

Ngah, R., \& Jusoff, K. (2009). Tacit knowledge sharing and SMEs' organizational performance. International Journal of Economics and Finance, 1(1), 216. https://doi.org/10.5539/ijef.v1n1p216 
Ngwangwama, M.M., Ungerer, M., \& Morrison, J. (2013). An exploratory study of key success factors for business success of companies in the Namibian tertiary industry. International Journal of Innovations in Business, 2(6), 604-629.

O'Cass, A., \& Sok, P. (2013). Exploring innovation driven value creation in B2B service firms: The roles of the manager, employees, and customers in value creation. Journal of Business Research, 66(8), 1074-1084. https://doi.org/10.1016/j. jbusres.2012.03.004

O'Dwyer, M., Gilmore, A., \& Carson, D. (2009). Innovative marketing in SMEs. European Journal of Marketing, 43(1/2), 46-61. https://doi.org/10.1108/ 03090560910923238

Onkelinx, J., Manolova, T.S., \& Edelman, L.F. (2015). Human capital and SME internationalization: Empirical evidence from Belgium. International Small Business Journal, 34(6), 818-837. https://doi.org/10.1177/0266242615591856

Peris Bonet, F., Rueda Armengot, C., \& Ángel Galindo Martín, M. (2011). Entrepreneurial success and human resources. International Journal of Manpower, 32(1), 68-80. https://doi.org/10.1108/01437721111121233

Phillipson, J., Bennett, K., Lowe, P., \& Raley, M. (2004), Adaptive responses and asset strategies: The experience of rural micro-firms and foot and mouth disease. Journal of Rural Studies, 20, 227-243. https://doi.org/10.1016/j.jrurstud.2003.08.006

Raymond, L., \& Bergeron, F. (2008). Enabling the business strategy of SMEs through e-business capabilities: A strategic alignment perspective. Industrial Management \& Data Systems, 108(5), 577-595. https://doi.org/10.1108/02635570810876723

Reijonen, H., \& Komppula, R. (2007). Perception of success and its effect on small firm performance. Journal of Small Business and Enterprise Development, 14(4), 689-701. https://doi.org/10.1108/14626000710832776

Riquelme, H., \& Watson, J. (2002). Do venture capitalists' implicit theories on new business success/failure have empirical validity? International Small Business Journal, 20(4), 395-420. https://doi.org/10.1177/0266242602204002

Schmidpeter, R., \& Weidinger, C. (2014). Linking business and society: An overview. In C. Weidinger (Ed.), Business success through sustainability (pp. 287-301). BerlinHeidelberg: Springer. https://doi.org/10.1007/978-3-642-38753-1_1

Shailer, G. (1989). The predictability of small enterprise failures: Evidence and issues. International Small Business Journal, 7(4), 54-58. https://doi.org/ $10.1177 / 026624268900700405$

SME Corp (2016). SME Annual Report 2016/2016. Retrieved 5 December 2016 from http://www.smecorp.gov.my/index.php/en/sme-annual-report-2015-16.

Solomon, G., Frese, M., Friedrich, C., \& Glaub, M. (2013). Can personal initiative training improve small business success? A longitudinal South African evaluation study. The International Journal of Entrepreneurship and Innovation, 14(4), 255-268. https://doi.org/10.5367/ijei.2013.0129

Steenkamp, N., \& Kashyap, V. (2010). Importance and contribution of intangible assets: SME managers' perceptions. Journal of Intellectual Capital, 11(3), 368-390. https://doi.org/10.1108/14691931011064590 
Stockdale, R., \& Standing, C. (2004). Benefits and barriers of electronic marketplace participation: An SME perspective. Journal of Enterprise Information Management, 17(4), 301-311. https://doi.org/10.1108/17410390410548715

Thurik, M. (2007). Policy induced constraints on small enterprise development in Asian developing countries: Small enterprise development. Journal of Small Business, $5(2), 66-77$.

Tunc Bozbura, F. (2007). Knowledge management practices in Turkish SMEs. Journal of Enterprise Information Management, 20(2), 209-221. https://doi. org/10.1108/17410390710725788

Valacich J.S., \& Schneider, S. (2014), Enhancing information system today: Managing in the digital world (6th ed.). Boston M.A.: Pearson Education.

Van Auken, H., \& Werbel, J. (2006). Family dynamic and family business financial performance: Spousal commitment. Family Business Review, 19(1), 49-63. https://doi.org/10.1111/j.1741-6248.2006.00059.x

Van Praag, C. M.(2003). Business survival and success of young small business owners. Small Business Economics, 21(1), 1-17. https://doi.org/10.1023/A:1024453200297

Vinayak, K., \& Kodali, R. (2014). Reliability and validity of new product development practices in Indian manufacturing industries. Journal of Advances in Management Research, 11(1), 82-101. https://doi.org/10.1108/JAMR-09-2012-0043

Wang, Z., \& Wang, N. (2012). Knowledge sharing, innovation and firm performance. Expert Systems with Applications, 39(10), 8899-8908. https://doi.org/10.1016/j. eswa.2012.02.017

White, A., Daniel, E., Ward, J., \& Wilson, H. (2007). The adoption of consortium B2B e-marketplace: An exploratory study. The Journal of Strategic Information Systems, 16(1),71-103. https://doi.org/10.1016/j.jsis.2007.01.004

Wieder, B., Booth, P., Matolcsy, Z.P., \& Ossimitz, M.L. (2006). The impact of ERP systems on firm and business process performance. Journal of Enterprise Information Management, 19(1), 13-29. https://doi.org/10.1108/17410390610636850

Yunus, A.R., Aris, A., Majid, I.A., \& Saad, M.S.M. (2014). FELDA youth entrepreneurs and personality-environment congruency. The Journal of Technology Management and Technopreneurship (JTMT), 2(1), 37-49.

Zucchella, A., \& Siano, A. (2014). Internationalization and innovation as resources for SME growth in foreign markets: A focus on textile and clothing firms in the Campania Region. International Studies of Management \& Organization, 44(1), 21-41. https://doi.org/10.2753/IMO0020-8825440102 